\title{
STRATEGI EDUTAINMENT DALAM PEMBELAJARAN DI PAUD (Studi Kasus Pada TK di Kota Cirebon)
}

\author{
Aip Saripudin \\ Dosen IAIN Syekh Nurjati Cirebon \\ E-mail: doubleaip82@gmail.com
}

Orcid Id: http://orcid.org/0000-0003-1815-9274

Isnaeni Yuningsih Faujiah

Pendiri Rumah Elmu Majalengka

E-mail: isnasabar12@gmail.com

Article received: 20 Februari 2018, Review process: 01 Maret 2018

Article published: 30 Maret 2018

\begin{abstract}
Learning strategy is one of the process of learning that the purpose of learning can achieved properly. In general commonly encountered learning in an PAUD institution who apply a concept education thrilling, unpleasant, even accompanied by attitude authoritarian to school tuition. This would have been totally no longer effective if seen than the results. Children educated by method and strategy this can be a generation by the tension, easy stress, and unable to solve problems in his life. One strategy can be used on learning in early childhood is edutainment strategy. One of the schools that has implemented learning with strategy edutainment is TK Pelangi Cirebon city. This Research used based on the qualitative descriptive. The objectives of research is described how edutainment strategy has been implemented on the PAUD with a focus on the planning aspect, the implementation as well as evaluation carried out. From the research, so obtained the data that strategy edutainment of which is used in PAUD is the various methods as a method of playing, method of story telling, method of sings, a method of role playing, the practice of direct and of computer use. Edutainment national access to justice strategy has been creates an atmosphere of learning to promote disorder to quality of being congenial, effective and more substantial.
\end{abstract}

Keywords: Edutainment, Strategy, Learning and Early Childhood.

\begin{abstract}
Abstrak
Strategi pembelajaran merupakan salah satu jurus untuk melakukan proses pembelajaran agar tujuan pembelajaran bisa tercapai dengan baik. Secara umum sering ditemui pembelajaran di lembaga PAUD yang menerapkan sebuah konsep pendidikan menegangkan, tidak menyenangkan, bahkan disertai dengan sikap otoriter kepada peserta didik. Hal ini tentu sudah tidak efektif lagi jika dilihat dari hasil yang dicapai. Sebab, anak yang dididik dengan metode dan strategi yang demikian justru akan menjadi generasi yang penuh dengan ketegangan, mudah stres, dan tidak mampu memecahkan masalah dalam kehidupannya. Salah satu strategi yang dapat digunakan pada pembelajaran anak usia dini saat ini adalah strategi edutainment. Salah satu sekolah yang telah menerapkan pembelajaran dengan strategi Edutainment adalah TK Pelangi Kota Cirebon. Penelitian ini menggunakan pendektan kualitatif deskriptif. Adapun tujuan penelitian adalah mendeskripsikan bagaimana strategi edutainment telah diimplementasikan pada sekolah tersebut dengan fokus pada aspek perencanaan, pelaksanaan serta evaluasi. Dari hasil penelitian, maka diperoleh data bahwa strategi edutainment yang digunakan di sekolah tersebut menckup berbagai metode seperti metode bermain, metode bercerita, bernyanyi, metode bermain peran, praktek langsung dan pemanfaatan komputer. Strategi edutainment telah menciptakan suasana pembelajaran menjadi menyenangkan, efektif dan berbobot.
\end{abstract}

Kata Kunci: Strategi, Edutainment, Pembelajaran dan Anak Usia Dini. 


\section{PENDAHULUAN}

Pendidikan merupakan bagian penting dalam menumbuh kembangkan anak didik bangsa Indonesia. Keberhasilan dalam membangun pendidikan pun menjadi tujuan utama untuk keberhasilan pendidikan di Indonesia. Salah satunya adalah lembaga pendidikan anak usia dini. Di mana untuk menjadikan anak didik tumbuh menjadi yang dibanggakan karena pendidikannya yang dilangsungkan sejak usia dini. UU No. 20 Tahun 2003 tentang sistem pendidikan nasional menyatakan bahwa pendidikan terdiri atas pendidikan anak usia dini, pendidikan dasar, pendidikan menengah, dan pendidikan tinggi, keseluruhannya merupakan kesatuan yang sistemik. Artinya, pendidikan harus dimulai dari usia dini, yaitu Pendidikan Anak Usia Dini (PAUD). PAUD diselenggarakan sebelum jenjang pendidikan dasar.PAUD dapat diselenggarakan melalui jalur pendidikan formal, nonformal, atau informal. PAUD pada jalur pendidikan formal berbentuk Taman Kanak-Kanak (TK), Raudhatul Athfal (RA), atau bentuk lain yang sederajat. PAUD pada jalur pendidikan nonformal berbentuk kelompok bermain (KB), taman penitipan anak (TPA). PAUD pada jalur pendidikan informal berbentuk pendidikan keluarga atau pendidikan yang diselenggarakan oleh lingkungan.

Strategi pembelajaran merupakan salah satu jurus untuk melakukan proses pembelajaran agar tujuan pembelajaran bisa tercapai dan materi pembelajaran bisa tersampaikan dengan baik. Sedangkan metode pembelajaran yang diterapkan guru di kelas menjadi faktor penyebab lainnya, terkadang guru menerapkan metode yang kurang sesuai dengan kondisi sekolah dan anak didik sehingga mengakibatkan kejenuhan di dalam pembelajaran.

Edutaintment merupakan salah satu strategi pembelajaran dalam pendidikan. Karena edutaintment sendiri sebagai salah satu proses pembelajaran yang menyenangkan yang dapat dijadikan sebagai suatu hiburan, bukan lagi menjadi sesuatu yang ditakutkan oleh anak didik. Sehingga kecemasan pembelajaran yang menarik akan menjadi pusat perhatian yang menarik dimata anak didik.

Dalam Al-qur'an sendiri digambarkan bahwa hidup ini sebenarnya sebuah permainan dan senda gurau, artinya janganlah menghadapi sesuatu masalah dalam hidup ini dengan stress, ketergesa-gesaan, tekanan mental seperti hidup dan mati.Karena hakekat hidup adalah sebuah permainan sandiwara, artinya semua orang memiliki perannya sendiri untuk tampil didepan panggung dan kapan harus masuk ruangan belakang atau dalam pementasan, semua memiliki 
sekenario sendiri sesuai lakon. Penjelasan Al-qur'an yang mengilustrasikan kehidupan dunia ini permainan dan senda gurau terdapat dalam surat $\mathrm{Al}$-an'am ayat 32 yang artinya

"Sesungguhnya kehidupan dunia hanyalah permainan dan senda gurau. Dan jika kamu beriman dan bertakwa, Allah akan memberikan pahala kepadamu dan Dia tidak akan meminta harta-hartamu" (Qs. Muhammad: 36).

Dalam dunia pendidikan pun sama, siapapun itu yang bergerak dalam dunia pendidikan harus menciptakan suasana kegiatan belajar mengajar yang menyenangkan. Makna kesenangan di sini adalah bagaimana dalam kegiatan pendidikan tidak ada tekanan-tekanan mental dan fisik baik pada diri pendidik maupun peserta didik sehingga kegiatan melaksanakan pembelajaran dalam kondisi senang, pikiran jernih, tidak tegang dan terciptanya suasana yang mendorong tumbuh kembangnya fisik, mental serta berbagai kecerdasan peserta didik. Namun demikian pelaksanaan pembelajaran harus dilakukan dengan kesungguhan, keseriusan, kedisiplinan, kejujuran, serta berbagai sifat lainnya (Mulyono, 2012: 182-185).

\section{KONSEP STRATEGI EDUTAINMENT}

Strategi pembelajaran dalam bukunya Evelin Siregar dan Hartini Nara (2011: 78) strategi pembelajaran adalah suatu rencana untuk mencapai tujuan.Strategi pembelajaran tersebut terdiri dari metode, teknik dan prosedur yang mampu menjamin peserta didik dapat mencapai tujuan aiakhir kegiatan pembelajaran.Sedangkan menurut Kemp dalam bukunya Trianto (2011: 82-83) strategi pembelajaran adalah suatu kegiatan pembelajaran yang dilakukan guru serta peserta didik untuk mencapai tujuan pembelajaran secara efektif dan efisien.

Strategi pembelajaran pada hakikatnya terkait dengan perencanaan atau kebijakan yang dirancang di dalam pengelola pembelajaran untuk mencapai tujuan pembelajaran yang diinginkan.Strategi pembelajaran ini erat hubungannya dengan teknik pembelajaran adalah implementasi dari metode pembelajaran yang berlangsung di dalam kelas. Edutainment adalah sebagai program pendidikan atau pelatihan yang dikemas dalam konsep hiburan sedemikian rupa, sehinggaltiap-tiap peserta didik hamper tidak menyadari bahwa mereka sebenarnya sedang diajak untuk belajar atau untuk memahami nilai-nilai (value) setiap individu.(Pangastuti, 2014:60).

Munculnya konsep edutainment yang mengupayakan proses pembelajaran yang kondusif dan menyenangkan, telah membuat suatu asumsi bahwa: pertama, perasaan positif (senang/gembira) akan mempercepat pembelajaran, kedua, jika seseorang mampu menggunakan potensi nalar dan emosi secara jitu, maka ia akan membuat loncatan prestasi belajar yang tidak 
terduga sebelumnya, ketiga, bila setiap pembelajar dapat dimotivasi secara tepat dan diajar dengan cara yang benar, cara yang menghargai gaya belajar dan modalisasi mereka, mereka semua akan mendapatkan hasil belajar yang optimal. Hakikat edutainment adalah upaya mengembalikan kondisi peserta didik sesuai dengan hakikat diri peserta didik sebagai manusia, dengan meyakinkan bahwa setiap peserta didik memiliki potensi diri yang dapat ditumbuhkembangkan dengan proses pembelajaran yang dijalaninya, motivasi setiap peseta didik untuk dapat menggunakan modalitas belajar mereka sehingga menjadikannya manusia pembelajar.

Dalam bukunya Fadillah (2014: 4-5) menurut Hamruni menjelaskan ada 3 alasan yang melandasi munculnya konsep edutainment, yaitu:

a. Perasaan positif (senang/gembira) akan mempercepat pembelajaran, sedangakn perasaan negatif, seperti sedih, takut, terancam, dan merasa tidak mampu, akan memperlambat belajar atau bahkan bisa menghentikan sama sekali. Oleh karenanya konsep edutainment berusaha memadukan antara pendidikan dan hiburaan. Hal ini dimaksudkan supaya pembelajaran berlangsung menyenangkan atau menggembirakan.

b. Jika seseorang mampu menggunakan potensi nalar dan emosinya secara jitu, maka akan membuat loncatan prestasi belajar yang tidak terduga sebelumnya.

c. Apabila setiap pembelajar dapat dimotivasi dengan tepat dan diajar dengan cara yang benar, cara yang menghargai gaya belajar dan modalitas mereka. Maka mereka semua akan dapat mencapai hasil belajar yang optimal.

Berangkat dari ketiga asumsi itulah yang kemudian memunculkan konsep edutainment. Tujuannya supaya pembelajar bisa mengikuti dan mengalami proses pembelajaran dalam suasana yang gembira, menyenangkan, menghibur, dan mencerdaskan. Dalam konteks ini, dapat dipahami bahwa prinsip belajar berbasis edutainment adalah pembelajaran harus dilakukan dengan cara menyenangkan, aman, nyaman dan membangkitkan semangat peserta didik. Ada 4 hal yang menjadi karakteristik dari konsep edutainment, yaitu:

a. Konsep edutainment adalah suatu rangkaian pendekatan dalam pembelajaran untuk menjebatani jurang yang memisahkan antara proses mengajar dan proses belajar, sehingga diharapkan dapat Ameningkatkan hasil belajar.

b. Konsep dasar edutainment berupaya agar pembelajaran yang terjadi berlangsung dalam suasana yang kondusif dan menyenangkan. 
c. Konsep edutainment menawarkan suatu sistem pembelajaran yang dirancang dengan satu jalinan yang efisien, meliputi diri anak didik, guru, proses pembelajaran, dan lingkungan pembelajaran. Konsep edutainment menempatkan anak sebagai pusat dari proses pembelajaran, sekaligus sebagai subjek pendidikan.

d. Dalam konsep edutainment, proses dan aktivitas pembelajaran tidak lagi tampil dalam wajah yang menakutkan, tetapi dalam wujud yang humanis dan dalam interaksi edukatif yang terbuka dan menyenangkan. Interaksi edukatif ini akan membuahkan aktivitas belajar yang efektif dan menjadi kunci utama suksesnya sebuah pembelajaran. Asumsinya, jika setiap manusia menggunakan potensi nalar 0okdapat diduga sebelumnya, bila seseorang mampu mengenali tipe belajarnya dan melakukan pembelajaran yang sesuai maka belajar akan terasa menyenangkan dan akan memberi hasil yang optimal.

Menurut Pangastuti (2014: 66-68) ada beberapa macam metode di dalam strategi edutainment pendidikan anak usia dini, diantaranya:

\section{a. Metode Bermain}

Para pakar mengatakan bahwa dunia anak adalah dunia bermain, bermain memiliki peran penting dalam mengembangkan segala aspek perkembangan anak, menurut Gordon dan Browne dalam Moeslichatoen, bermain merupakan kegiatan yang memberikan kepuasan bagi diri sendiri.Melalui bermain anak memperoleh pembatasan dan memahami kehidupan, bermain merupakan kegiatan yang memberikan kesenangan dan dilaksanakan untuk kegiatan itu sendiri yang lebih ditekankan pada hasil yang diperoleh dari kegiatan itu sendiri.

\section{b. Metode karya wisata}

Karya wisata merupakan mengajak siswa ke luar kelas dan meninjau atau mengunjungi objek-objek lainnya sesuai dengan kepentingan pembelajaran. Metode karya wisata juga merupakan salah satu metode yang melaksanakan kegiatan pengajaran dengan cara mengamati dunia sesuai dengan kenyataan yang ada secara langsung meliputi manusia, hewan, tumbuhtumbuhan, dan benda-benda lainnya, dengan mengamati secara langsung anak memperoleh kesan yang sesuai dengan pengamatannya.

\section{c. Metode bercakap-cakap}

Dalam kegiatan bercakap-cakap tiap anak terlibat dalam kegiatan itu ingin membicarakan segala sesuatu yang dikutahui, dimiliki dan dialami kepada anak lain atau gurunya. Bercakapcakap mengandung arti belajar mewujudkan kemampuan berbahasa reseptif dan ekspesif, anak akan mengembangkan bermacam kosa kata dalam berbagai tema yang akan mengacu 
pengembangan berbagai aspek perkembangan anak. Semakin banyak kosakata yang diperolehnya dari bermacam tema yang ditetapkan semakin luas perbendaharaan pengetahuan anak tentang diri sendiri, keluarga, sekolah, dunia tanaman, hewan, orang, pekerjaan, dan sebagainya.Saling mengkomunikasikan pikiran, perasaan, dan kebutuhan secara verbal.

\section{d. Metode bernyanyi}

Bernyanyi merupakan mengeluarkan suara dengan syair-syair yang digunakan.Mengelola kelas dengan bernyanyi berarti menciptakan dan mengelola pembelajaran dengan menggunakan syair-syair yang dilagukan. Biasanya disesuaikan dengan tema yang akan diajarkan.

Manfaat medode bernyanyi adalah membuat suasana menjadi riang dan bergairah sehingga perkembangan anak dapat distimulasi secara lebih optimal, karena pada prinsipnya tugas lembaga PAUD adalah untuk mengembangkan seluruh aspek dalam diri anak, meliputi motorik, bahasa, kognitif, seni, moral dan sosial emosional (Fadillah dkk, 2014: 42-43).

\section{e. Metode demonstrasi}

Metode demonstasi dan eksperimen adalah suatu upaya untuk praktek dengan penggunaan peragaan yang ditujukan pada peserta didik yang tujuannya ialah agar semua siswa lebih mudah diperolehnya dan dapat menguasi suatu permasalahan apabila terdapat perbedaan.

\section{f. Metode bercerita}

Metode bercerita merupakan pemberian pengalaman belajar bagi anak usia dini dengan membawakan cerita kepada anak secara lisan, cerita yang dibawakan guru harus menarik, mengundang perhatian anak dan tidak lepas dari tujuan pendidikan anak usia dini. Metode bercerita dalam kegiatan pembelajaran anak mempunyai beber apa manfaat penting bagi pencapaian tujuan pendidikan anak usia dini. Bagi anak usia dini mendengarkan cerita yang menarik yang dekat dengan lingkungannya merupakan kegiatan yang mengasyikkan. Guru TK yang terampil bertutur dan kreatif dalam bercerita dapat memanfaatkan kegiatan bercerita untuk menanamkan kejujuran, keberanian, kesetiaan, keramahan, ketulusan, dan sikap-sikap positif yang lain dalam kehidupan lingkungan keluarga, sekolah, dan luar sekolah. Kegiatan bercerita juga memberikan sejumlah pengetahuan sosial, nilai-nilai moral dan keagamaan.Kegiatan bercerita memberikan pengalaman belajar untuk melatih mendengarkan.Melalui mendengarkan anak memperoleh bermacam informasi tentang pengetahuan, nilai, dan sikap untuk dihayati dan diterapkan dalam kehidupan sehari-hari. 


\section{g. Metode proyek}

Metode proyek merupakan salah satu cara pemberian pengalaman belajar dengan menghadapkan anak-anak dengan persoalan-persoalan sehari-hari yang harus dipecahkan secara berkelompok, metode proyek berasal dari gagasan John Dewey tentang konsep learning by doing yakni proses perolehan hasil belajar dengan mengerjakan tindakan-tindakan tertentu sesuai dengan tujuannya terutama proses penugasan anak tentang bagaimana melakukan pekerjaan yang terdiri atas serangkaian tingkah laku untuk mencapai tujuan misalnya melipat kertas, memasang tali sepatu, menganyam, membentuk model binatang atau bangunan atau sebagainya.

\section{h. Pemanfaatan komputer}

Komputer kini tengah menjadi salah satu tren media pembelajaran alternative untuk anak usia dini. Saat ini kian berkembangnya software-software dengan program tertentu dalam bentuk $\mathrm{CD}$ interaktif untuk membantu pembelajaran untuk anak usia dini. CD interaktif yang ditawarkanpun sangat beragam jenisnya mulai dari pembelajaran umum hingga pembelajaran yang sifatnya islami.Mulai dari pengenalan huruf alphabet, angka-angka, warna, bentuk geometri dan lain-lain.Contoh dari CD islami yaitu pengenalan huruf hijaiyah, shalat, wudhu, dan lainlain.Metode yang ditampilkan oleh CD interaktif pun bermacam-macam, ada yang menggunakan metode bernyanyi, bercerita, permainan atau bahkan kombinasi dari beberapa metode dan tentunya dikemas secara interaktif sehingga terdapat keterlibatan terhadap diri anak.

Pembelajaran melalui CD interaktif yang diterapkan pada anak usia dini tentunya dapat memberikan manfaat dalam menstimulasi beberapa kecerdasan. Misalnya, kecerdasan kognitif yaitu dengan bertambahnya pengetahuan anak dan kemampuan anak dalam memahami sesuatu.Kecerdasan bahasa, yaitu yang dapat dilihat dari bertambahnya kosakata anak. Hal lain yang dapat dikembangkan dari pembelajaran melalui komputer bagi anak adalah stimulasi bagi perkembangan antara koordinasi mata dengan ketepatan gerak tangan. Secara tidak langsung pembelajaran melalui komputer juga menstimulasi bagi perkembangan motorik halus anak.

\section{LANDASAN STRATEGI EDUTAINMENT}

Dalam proses pembelajaran terdapat banyak teori yang telah diungkapkan oleh para ahli pendidikan maupun psikologis. Teori ini berkaitan dengan bagaimana cara memperlakukan peserta didik dalam kegiatan pembelajaran, sehingga mampu menerima dan menangkap materi yang disampaikan pendidik dengan baik. Melalui teori yang ada, seseorang dapat memilih teori mana yang tepat untuk pembelajaran, serta mampu mengarahkan dan menciptakan pembelajaran 
yang mengasyikkan dan menyenangkan. Adapun untuk teori pembelajaran berbasis edutainmentakan dijelaskan dibahwah ini:

\section{a. Teori belajar kooperatif}

Pendekatan belajar kooperatif sangat dikenal pada tahun 1990-an, Oxford Dictionary mendefinisikan kooperasi (cooperation) sebagai "bersedia untuk membantu". Kooperatif juga berarti bekerja sama untuk mencapai tujuan secara efektif dan efisien.

Teori belajar dengan kerja sama (kooperatif) merupakan teori pembelajaran yang menggunakan kelompok kecil siswa, sehingga mereka dapat menjalin kerja sama untuk memaksimalkan kelompoknya dan masing-masing melakukan pembelajaran. Teori belajar kooperatif adalah teori belajar yang bersifat kerja sama antara satu siswa dengan siswa yang lain. Pendapat lain menyebutkan bahwa teori belajar kooperatif merupakan rangkaian kegiatan belajar yang dilakukan oleh siswa dalam kelompok tertentu untuk mencapai tujuan pembelajaran yang telah dirumuskan.

Ada beberapa unsur dasar pembelajaran kooperatif, diantaranya adalah peserta didik dalam kelompoknya haruslah beranggapan bahwa mereka sehidup sepenanggungan bersama, peserta didik harus bertanggung jawab atas segala sesuatu di dalam kelompoknya seperti milik mereka sendiri, semua anggota dalam kelompoknya memiliki tujuan yang sama, intinya pembelajaran kooperatif prinsipnya adalah bahwa peserta didik saling bertukar pikiran dan saling membantu dalam kegiatan pembelajaran. Artinya, dalam pembelajara ini masing-masing peserta didik lebih ditekankan untuk saling bekerja sama antara satu dengan yang lainnya (Fadillah dkk, 2014: 11-12).

\section{b. Teori Otak Triun}

Otak triun merupakan istilah yang menggambarkan tentang otak manusia yang terdiri dari tiga bagian.Ketiga bagian tersebut dikenal pula dengan tritunggal atau 3 in 1.Dr. Paul Mac Lean menyebutkan otak triun karena terdiri dari tiga bagian, masing-masing berkembang pada waktu yang berbeda dalam sejarah evolusi manusia.Masing-masing bagian juga mempunyai struktur saraf tertentu dan mengatur tugas-tugas yang harus dilakukan.Yang termasuk dalam bagian otak triun, yaitu otak reptile (batang otak), sistem limbik (otak mamalia), dan otak neokorteks. (Fadillah dkk, 2014: 13-15).

\section{c. Teori Kecerdasan Majemuk}

Dalam bukunya Mulyasa (2012: 57-59) menjelaskan beberapa kecerdasan majemuk pada anak usia dini, memang pada masa ini ketujuh kecerdasan belum berkembang secara optimal, 
tetapi ada kalanya kecerdasan tersebut sudah mulai tampak. Salah satu cirinya adalah anak dapat menampilkan kemampuannya melebihi teman-teman sebayanya. Seorang anak yang mempunyai kecerdasan musikalitas apa umumnya dengan cepat dapat menirukan nada dengan tepat, atau menghafal lagu dengan cepat. Anak-anak ini perlu diberi rangsangan dengan mengajaknya untuk bernyanyi atau bermain musik agar kemampuannya berkembang.

Salah satu ciri anak yang memiliki kecerdasan matematika adalah memiliki kemampuan dan kesenangan dalam berhitung.Anak-anak yang demikian perlu dirangsang dengan dihadapkan dengan permasalahan-permasalahan yang ada sangkut pautannya dengan angka. Anak-anak yang mempunyai kecerdasan di bidang kinestetik dapat terdeteksi melalui kemampuannya yang berhubungan dengan kelenturan tubuh, misalnya menari atau olahraga.Untuk mengembangkan kemampuannya, anak-anak tersebut perlu diajak untuk menari atau melakukan kegiatan-kegiatan yang memerlukan gerakan-gerakan tubuh. Kecerdasan linguistik dipunyai oleh anak-anak yang gemar membaca atau bercerita.Dengan demikian, untuk mengembangkan kecerdasan kebahasaan anak-anak tersebut perlu diberi rangsangan dengan diajak membaca dan mengungkapkannya. Anak-anak mempunyai kemampuan untuk mengingat tempat atau mengetahui posisi-posisi dengan tepat, berarti yang bersangkutan mempunyai kecerdasan spasial atau kecerdasan ruang.Untuk meningkatkan kecerdasam tersebut anak-anak perlu dirangsang dengan permainan-permainan yang terkait dengan ruang, salah satunya adalah bermain puzzle. Kecerdasan interpersonal adalah kecerdasan untuk memahami hal-hal yang terjadi pada dirinya.Kecerdasan ini ditandai dengan kemampuannya untuk mengungkap perasaan atau isi hati. Kecerdasan ini dapat dikembangkan dengan cara anak-anak diminta untuk mengungkapkan apa yang yang terjadi dan apa yang dirasakan. Kecerdasan intrapersonal adalah kecerdasan seseorang untuk menjalin hubungan dengan orang lain. Mengajak anak bergaul dengan temantemannya baik teman lama maupun teman yang baru dikenalnya akan sangat membantu dalam upaya mengembangkan kecerdasan intrapersonal ini.

Ketujuh kecerdasan ini perlu dikembangakan sejak anak masih usia dini. Karena masamasa tersebut adalah masa golden age.Pada masa tersebut kecerdasan dapat berkembang paling optimal, karena pada masa itulah anak-anak paling peka untuk menangkap segala rangsangan yang masuk dalam dirinya.Hal ini sesuai dengan teori yang dikemukakan oleh John Locke, yaitu teori tabularasa yang mengibaratkan anak sebagai meja yang terbuat dari lilin. Makna teori ini adalah anak dapat dibentuk apa saja bergantung pada pendidiknya. 


\section{PENGGUNAAN EDUTAINMENT DALAM PEMBELAJARAN}

Perencanaan pembelajaran edutainment sama seperti proses pembelajaran yang aktif, kreatif, inovatif, efektif, dan menyenangkan yang dapat dilakukan oleh anak yang disiapkan oleh pendidik melalui kegiatan-kegiatan yang menarik, menyenangkan untuk membangkitkan rasa ingin tahu anak, memotivasi anak untuk berpikir kritis, dan menemukan hal-hal baru. Pengelolaan pembelajaran hendaknya dilakukan secara demokratis, mengingat anak merupakan subjek dalam proses pembelajaran. (Trianto, 2011: 75).

Sebelum memberikan pembelajaran kepada anak, hendaknya memahami hal-hal yang perlu diperhatikan, yaitu (a) Menciptakan lingkungan belajar tanpa stress (rileks), lingkungan yang nyaman dan aman, harapan untuk sukses tinggi menjulang. (b) Menjamin bahwa sejak awal pebelajaran adalah relevan, karena harus memahami bahwa belajar akan berjalan dengan efektif jika yang ersangkutan paham akan pentingnya pelajaran tersebut. (c) Melibatkan secara sadar semua indra dan juga pikiran, baik yang terdapat dalam otak kanan maupun otak kiri. (d) Menantang otak untuk dapat berfikir jauh ke depan dan mengeksplorasi apa yang sedang dipelajari sebanyak mungkin. (e) Menggabungkan semua bahan yang dipelajari dengan tetap, tenang dan nyaman. (f) Materi pelajaran yang dijarkan relevan dan bermakna. (g) Pembelajaran hendaknya bersifat soaial (membuat jalinan kerja sama di antara murid). (g) Hakikat belajar adalah memahami dan menciptakan sendiri makna dan nilai yang dipelajari, menjadikan aktivitas fisik sebagai bagian dari proses belajar. (h) Belajar hendaknya melibatkan mental dan tindakan sekaligus. (i) Isi dan rancangan pembelajaran hendaknya bisa mengakomodasi ragam kecerdasan yang dimiliki pembelajar (Suyadi, 2010: 231-232).

Pelaksanaan pembelajaran berdasrkan minat yang setiap hari dilakukan dengan menggunakan tiga tahapan kegiatan yaitu pembukaan/awal/pendahuluan, kegiatan inti, istirahat dan kegiatan penutup. (Trianto, 2013: 212-216).

\section{METODOLOGI}

Metode yang digunakan dalam penelitian ini menggunakan pendekatan kualitatif deskriptif. Melalui metode deskriptif maka peneliti mesti mendeskripsikan atau menggambarkan segala sesuatu yang diindrainya secara lengkap dan mandalam. Untuk itulah peneliti wajib membat catatan lapangan dan catatan wawancara yang rinci, lengkap dan apa adanya. Dalam konteks penelitian ini, maka yang akan diteliti adalah segala aktivitas yang berlansung di TK seperti proses pembelajaran di dalam maupun diluar kelas dan aktivitas lain yang sedang 
berlangsung. Karena itu deskripsi yang dibuat adalah tentang berbagai aktivitas sesuai dengan masalah dan fokus penelitian.

Sementara objek dari penelitian ini adalah TK Pelangi Kota Cirebon yang terletak di Jalan Perjuangan Kecamatan Kesambi Kota Cirebon. Subjek penelitian ini adalah ketua yayasan, kepala sekolah dan guru yang ada di TK Pelangi Kota Cirebon. Kemudian sumber dan jenis data yang yang diperlukan untuk dihimpun dan diolah dalam penelitian kualitatif berupa data primer dan data sekunder. Teknik pengu $5^{\mathrm{n}}$ data yang dilakukan oleh peneliti adalah untuk mengumpulkan informasi yang dibuıuindn melalui ketua yayasan, kepala sekolah, dan guru melalui observasi, wawancara dan dokumentasi. Teknik analisis data yang digunakan yakni dengan langkah-langkah, Reduksi Data (Data Reduction), Penyajian Data (Data Display), penarikan kesimpulan dan Verifikasi (Conclusion Drawing/Verification)

\section{HASIL DAN PEMBAHASAN}

Kegiatan pembelajaran dengan menggunakan strategi edutainment di TK Pelangi tercermin dalam kegiatan awal atau kegiatan apersepsi, kegiatan inti dan kegiatan akhir/evaluasi. Pembelajaran diawali dengan berbaris dan membaca ikrar di halaman sekolah pada umumnya dengan kegiatan pembukaan yang biasa dilakukan duduk melingkar di karpet. Guru menjelaskan tema yang akan dipelajari, guru merangsang kognitif anak dengan pertanyaan yang berkaitan dengan tema, jawaban setiap anak pasti berbeda-beda namun pada akhirnya guru menjelaskan dengan tema yang berkaitan.

Pada kegiatan inti ini seperti di RA atau TK pada umumnya menjelaskan semua kegiatan yang akan dilakukan, lalu anak mengerjakannya. namun berbeda di TK Pelangi ini. Pada kegiatan inti guru menjalaskan satu kegiatan lalu membimbing kegiatan tersebut sampai tuntas, setelah kegiatan pertama selesai guru melanjutkan ke kegiatan yang kedua dan seterusnya.

Selanjutnya pada kegiatan istirahat di TK Pelangi ini dilakukan di dalam kelas untuk makan bersama selama setengah jam. Untuk melatih kebersamaan dan berbagi dengan sesama teman. Selesai makan bersama anak-anak untuk istirahat di luar kelas dengan permainanpermainan yang telah disediakan. Kegiatan penutup ini anak duduk melingkar kembali di karpet dengan guru membahas kembali pembelajaran yang telah dilakukan.Hal ini untuk memperkuat ingatan anak-anak dalam pembelajaran yang telah dilakukan. Sejalan dengan komponen kedua pembelajaran anak usia dini bahwa urutan kegiatan pembelajaran terdiri atas pendahuluan, inti, istirahat dan penutup. (Trianto, 2013: 212-216). 
Keterangan diatas menunjukan urutan kegiatan pembelajaran yang ada di TK Pelangi selama peneliti melakukan penelitian hamper 3 bulan. Tentunya kami menemukan berbagai implementasi strategi edutainment telah diterapkan selama kegiatan pembelajaran berlangsung. Menarik dalam pembelajaran dengan menggunakan strategi edutainment yakni anak-anak tidak mudah bosan, pembelajaran menjadi efektif dan sangat menyenangkan. Salah seorang siswa mengatakan bahwa "belajar disini senang, tidak bosan". Begitupula dengan hasil wawancara dengan orang tua mengenai pembelajaran yang ada di TK Pelangi, mengatakan bahwa "anak saya jadi lebih aktif, tidak mudah jenuh apabila ada tugas dari sekolah"

Namun dari semua kegiatan pembelajaran dengan menggunakan strategi edutainment, terdapat faktor penghambat implementasi strategi edutainment dalam proses pembelajaran anak usia dini di TK Pelangi yakni:

1) Anak-anak yang memiliki karakter dan kepribadian yang berbeda, membuat guru harus memiliki kesabaran yang ekstra, karena ada saja anak yang kurang memperhatikan pembelajaran dan tugas guru harus membuat pembelajaran semenarik mungkin agar anakanak selalu berminat dan senang untuk belajar.

2) Ada beberapa orang tua yang beranggapan bahwa anaknya di sekolah TK harus bisa membaca dan menulis. Sehingga diadakannya pendidikan untuk orang tua agar memenuhi pengetahuan untuk orang tua tentang tidak dianjurkannya CALISTUNG pada anak usia dini. Kecuali untuk pengenalan yang dasar saja.

Sementara terdapat juga faktor pendukung implementasi strategi edutainment dalam proses pembelajaran anak usia dini di TK Pelangi Kota Cirebon sebagai berikut:

1) Para guru yang selalu semangat dan berjuang membuat pembelajaran semenarik mungkin. Mulai dari pembuatan RPPM, RPPH dan kegiatan pembelajaran yang sesuai dengan strategi edutainment.

2) Fasilitas yang menjadi modal untuk membantu para guru membuat atau menggunakan media alat peraga untuk setiap pembelajaran berlangsung.

Dari faktor penghambat pembelajaran di mana anak yang memiliki karakter dan kepribadian yang berbeda, sebagai seorang guru harus bisa memahami setaip anak dengan baik, agar tujuan pembelajaran tercapai. Sesuai dengan karakteristik anak usia dini oleh Hasnida (2014: 180-181) memaparkan bahwa pribadi setiap anak ini sangat unik. Karakter setiap anak berbeda-beda dan memiliki ciri khas masing-masing. Walaupun memiliki banyak kesamaan dalam pola umum perkembangan anak usia dini, akan tetapi anak mempunyai bakat, minat, gaya 
belajar, dan sebagainya. Hal ini sejalan dengan Haward Gardner dalam bukunya Fadillah (2014 : 7-18) yang meyebutkan delapan kecerdasan majemuk adalah linguistik, visual, kinestetik, naturalis, interpersonal, intrapersonal, logika-matematika dan musikal.

\section{IMPLEMENTASI STRATEGI EDUTAINMENT DALAM PEMBELAJARAN DI TK}

\section{a. Perencanaan Pembelajaran edutainment}

Rencana Pelaksanaan Pembelajaran Tahunan dan Semester pengurus rutin mengadakan rapat tahunan untuk mendiskusikan perencanaan yang akan direvisi atau tetap. Untuk tim penyusun sendiri semua pengurus TK Pelangi yang bersangkutan, termasuk kepala sekolah dan para guru masing-masing kelas.

Sedangkan untuk tim penyusun Rencana Program Pembelajaran Mingguan dan Harian (RPPM dan RPPH) disusun oleh para guru masing-masing kelas untuk merangkai kegiatan mingguan yang dituangkan pada kegiatan harian, namun tetap diadakan rapat bulanan atau mingguan untuk melakukan kesepakatan program yang telah disusun.

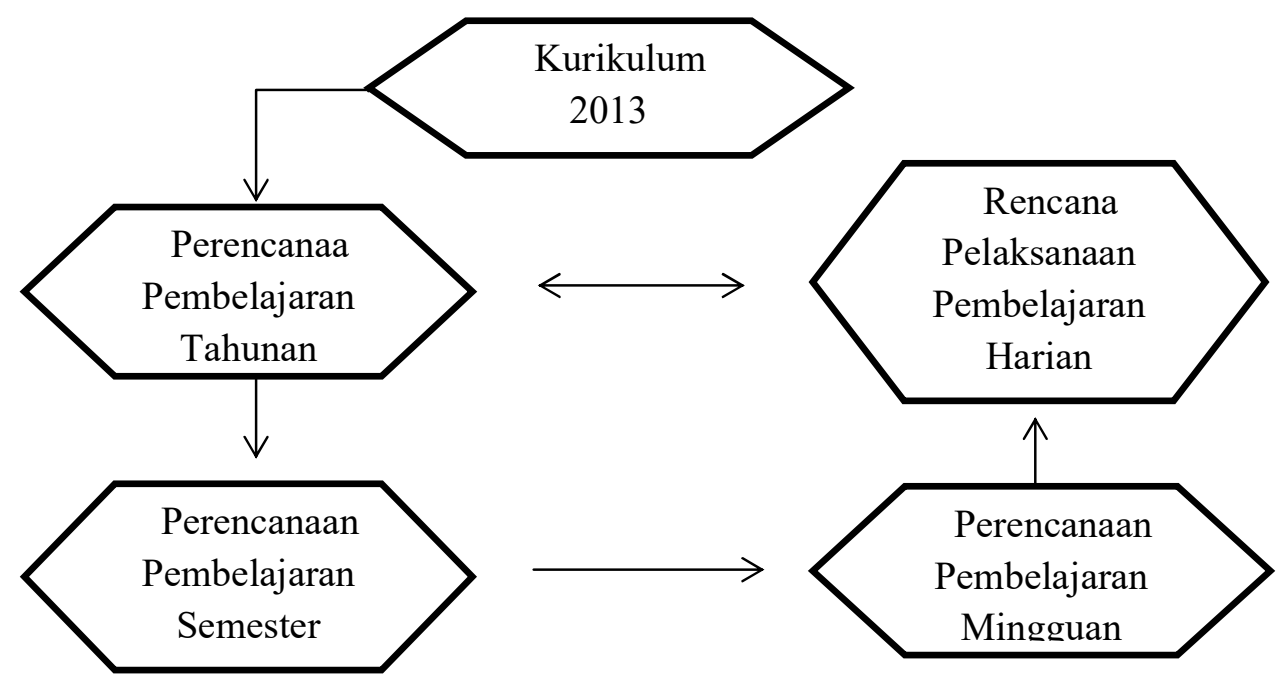

Bagan 1. Tahap Perencanaan Pembelajaran

Untuk menjabarkan bagan di atas mengenai peraturan menteri pendidikan dan kebudayaan republik Indonesia nomor 137 tahun 2014 tentang standar nasional pendidikan anak usia dini, bahwa kaitannya dengan standar proses BAB 5 pasal 11 mencakup (a) perencanaan pembelajaran, (b) pelaksanaan pembelajaran, (b) evaluasi pembelajaran.

Kurikulum 2013 menurut peraturan menteri pendidikan dan kebudayaan republik Indonesia nomor 146 tahun 2014. Dalam pasal 3 ayat (1) kurikulum PAUD disebut Kurikulum 2013 Pendidikan Anak Usia Dini. (2) Kurikulum 2013 Pendidikan Anak Usia Dini mengacu pada Standar Nasional Pendidikan Anak Usia Dini. Begitupun dalam pasal 5 ayat (1) Struktur 
Kurikulum PAUD menurut program-program pengembangan yang mencakup nilai agama dan moral, fisik motorik, kognitif, bahasa, sosial dan seni.

Sejalan dengan PERMENDIKBUD no 137 tentang standar nasional pendidikan anak usia dini pasal 12 (2) perencanaan pembelajaran meliputi program semester (prosem), rencana pelaksanaan pembelajaran mingguan (RPPM) dan rencana pelaksanaan pembelajaran harian (RPPH). Sedangkan pada pasal 13 ayat (1) tentang pelaksanaan pembelajaran sebagaimana dalam pasal 11 huruf $\mathrm{b}$ dilakukan bermain secara interaktif, inspiratif, menyenangkan, kontekstual dan berpusat pada anak untuk berpartisipasi aktif serta memberikan keleluasaan bagi prakarsa, kreativitas dan kemandirian sesuai dengan bakat, minat dan perkembangan fisik serta psikologis anak. Dilanjut pada pasal 15 ayat (2) pelaksanaan pembelajaran mencakup (a) kegiatan pembuka, (2) kegiatan inti dan (3) kegiatan penutup.

\section{b. Pelaksanaan Pembelajaran Edutainment}

Dari hasil pengamatan ada beberapa metode edutainment yang digunakan dalam pembelajaran, yaitu sebagai berikut:

1) Metode bermain

Pada hari kamis 06 april 2017, peneliti mencoba mengamati kelas A, di mana kelas A ini lebih cenderung terkenal sangat aktif-aktif anaknya. Saat itu dengan tema keagamaan yang dilaksanakan setiap hari kamis.Namun di sini guru sangat terlihat terampil untuk membuat pembelajaran menjadi menyenangkan. Karena pada saat akan memulai pembelajaran anak diajak untuk menirukan gerakan-gerakan yang dilakukan guru tersebut. Setelah anak puas dengan permainan meniru gerakan, guru mulai masuk pada pembelajaran dengan memulai gerakan shalat, namun guru menjelaskan bahwa shalat itu bukan gerakan permainan. Saat itu anak mulai mengikuti gerakan shalat sampai selesai. Ini salah satu senjata guru, sebelum ke pembelajaran yang diinginkan atau direncanakan guru, maka guru harus menuruti apa yang membuat anak senang dan semangat.

Sedangkan pada hari senin 10 april 2017, peneliti mencoba mengamati lagi pembelajaran di kelas A, karena dengan hasil yang kemarin masih penasaran dengan permainan apa saja yang dilakukan guru. Pada saat itu temanya air, udara dan api, tidak banyak alat peraga yang digunakan, namun permainan yang dilakukan guru ini masih sama seperti kemarin yaitu meniru gerakan. Tetapi gerakan yang ditirukan adalah lumba-lumba yang sedang melompat di air.Anak menirukan sambil melompat lalu duduk lagi dengan tertib, itu juga salah satu permainan yang dilakukan guru untuk membuat anak mulai siap belajar. 
Pada hari selasa 11 april 2017, peneliti mencoba mengamati kelas B. Karena kelas B ini lebih kesannya serius, dari pada kelas A yang banyak permainannya. Namun pikiran peneliti salah, saat baru saja akanmemulai pembelajaran, anak menirukan gerakan burung dengan kedua tangan yang tandanya bahwa burung terbang dengan bantuan udara atau angin. Karena pada saat itu temanya adalah udara. Tetapi ketika kelas tidak kondusif, ternyata guru memiliki jurus tersendiri untuk membuat anak menjadi fokus pada pembelajaran.Permainan melingkar, meniru garakan yang biasa dilakukan di kelas maupun di luar kelas.

Langkah-langkah metode bermain di TK Pelangi Kota Cirebon, yaitu sebagai berikut:

a) Guru memancing anak dengan genjring yang biasa dimainkan untuk mengambil perhatian anak.

b) Selanjutnya guru mengenalkan permainan apa yang akan dilakukan jika permainan itu baru, namun jika permainan itu biasa dimainkan anak maka guru hanya mengingatkan saja. Misalnya permainan melingkar berjalan sambil menyanyikan lagu, lalu ketika lagu berhenti anak diintruksikan untuk berpasangan dengan teman.

c) Setelah guru menjelaskan permainannya, maka untuk memulai dengan baik dan biasanya ketika anak senang dengan permainan tersebut ingin diulang beberapa kali.

Sejalan dengan para pakar mengatakan bahwa dunia anak adalah dunia bermain, bermain memiliki peran penting dalam mengembangkan segala aspek perkembangan anak, seperti perkembangan motorik, sosial emosional dan bahasa.Perkembangan motorik sendiri pada saat anak mengikuti permainan melingkar, menirukan gerakan.Perkembangan sosial emosional sendiri seperti saat anak diberi tugas untuk berpasangan dengan temannya. Dan perkembangan bahasa sendiri, anak mengikuti intruksi guru secara sadar ia mengikuti perintah guru. Menurut Gordon dan Browne dalam Moeslichatoen, bermain merupakan kegiatan yang memberikan kepuasan bagi diri sendiri.Melalui bermain anak memperoleh pembatasan dan memahami kehidupan, bermain merupakan kegiatan yang memberikan kesenangan dan dilaksanakan untuk kegiatan itu sendiri yang lebih ditekankan pada hasil yang diperoleh dari kegiatan itu sendiri (Pangastuti, 2014: 66).

Selain itu sesuai dengan pendapat Hurlock bahwa permainan dibagi menjadi dua, yaitu bermain aktif dan pasif.Bermain aktif sendiri yaitu yang permainannya yang dilakukan oleh anak itu sendiri. Sedangkan bermain pasif adalah anak memperhatikan anak lain yang sedang bermain. Di TK Pelangi ini lebih seringnya dengan bermain aktif, karena untuk memberikan kepuasan tersendiri terhadap anak (Fadillah dkk, 2014: 37). 
2) Metode bernyanyi

Metode bernyanyi ini membuat anak semangat dan senang dengan mengikuti pembelajaran.Nyanyian yang biasa dinyanyikan dengan lirik lagu yang gampang diingat dan dihafal oleh anak.Seperti bernyanyi sebelum memulai Berdo'a. Saat itu lagu sebelum belajar yang dinyanyikan dengan liriknya adalah "ibu jari, jari telunjuk, jari tengah yang panjang, jari manis pakai cincin, jari kelingking ku sayang. Ini satu, ini dua, ini tiga dan empat, angkat tangan sama-sama, mari kita berdo'a.” Selain lagu itu, banyak lagu sebelum berdo'a lainnya, namun pada saat itu yang peneliti amati lagu tersebut.

Di kelas A maupun kelas B, menggunakan lagu yang sama, seperti lagu akan pulang dengan lirik yaitu "illa liqo $2 \mathrm{X}$, sampai berjumpa pulang, illa liqo $2 \mathrm{X}$, sampai berjumpa lagi, buat apa nakal $2 \mathrm{X}$, nakal itu tak ada gunanya, buat apa malas $2 \mathrm{X}$, mala situ taka da gunanya". Kira-kira seperti itu lirik lagunya.

Langkah-langkah metode bernyanyi di TK Pelangi Kota Cirebon, yaitu sebagai berikut:

a) Bernyanyi yang biasa dilakukan ini tanpa intruksi terlebih dahulu, karena ketika guru sudah mulai mengucapkan kata awal dari syair lagu tersebut anak sudah mengerti dan langsung mengikutinya.

b) Kecuali ketika lagu yang akan dinyanyikan lagu baru dikenal oleh anak. Guru mengenalkannya dengan cara mengulang-ulang lagu tersebut untuk mengasah ingatan anak. Ketika anak terbiasa mendengarkan syair tersebut akan mengikuti dengan sendirinya.

Metode bernyanyi membuat suasana kelas menjadi riang dan bergairah sehingga perkembangan anak dapat distimulasi secara lebih optimal, karena pada prinsipnya tugas lembaga PAUD adalah untuk mengembangkan seluruh aspek dalam diri anak, meliputi motorik, bahasa, kognitif, seni, moral dan sosial emosional (Fadillah dkk, 2014: 42-43).

3) Metode karya wisata

Metode ini digunakan di kelas B pada saat tema air, udara, api dengan sub tema udara. Anak belajar di luar kelas untuk mengamati alam sekitarnya, untuk merasakan udara yang segar, untuk membuktikan pada anak bahwa udara tidak bisa dilihat, tetapi hanya bisa dirasakan. Sesuai dengan bukunya Pangastuti (2014: 67-68) bahwa metode karya wisata juga merupakan salah satu metode yang melaksanakan kegiatan pengajaran dengan cara mengamati dunia sesuai dengan kenyataan yang ada secara langsung meliputi manusia, hewan, tumbuh-tumbuhan, dan bendabenda lainnya, dengan mengamati secara langsung anak memperoleh kesan yang sesuai dengan pengamatannya. 
Langkah-langkah metode demonstrasi di TK Pelangi Kota Cirebon, yaitu sebagai berikut:

a) Persiapannya guru memilih tempat untuk dikunjungi anak. Misalnya halaman sekolah yang ada pohon-pohonnya.

b) Anak dikenalkan pada lingkungan sekitarnya seperti tumbuhan yang ada di sekitar halaman sekolah.

Serasi dengan langkah-langkah pokok dalam pelaksanaan metode karyawisata dalam bukunya Mulyasa (2011:11) yaitu perencanaan karyawisata dimana merumuskan tujuan karyawisata, menetapkan objek karyawisata sesuai dengan tujuan yang hendak dicapai, menetapkan lamanya karyawisata, menyusun rencana belajar bagi anak selama karyawisata dan merencanakan perlengkapan belajar yang harus disediakan.Pelaksanaan karyawisata.Yaitu pada fase ini adalah pelaksanaan kegiatan belajar di tempat karyawisata dengan bimbingan guru.Kegiatan belajar ini harus diarahkan kepada tujuan yang telah ditetapkan pada fase perencanaan di atas. Dan tindak lanjut adalah pada akhir karyawisata siswa diminta laporannya secara lisan (bercerita), mengenai apa yang telah mereka pelajari pada waktu karyawisata.

4) Metode pemanfaatan komputer atau elektronik

Metode ini di lakukan ketika menonton DVD yang telah tersedia di TK tersebut. Anak dilatih visualnya untuk merangsang perkembangan bahasa anak dengan apa yang telah dilihatnya. Hal ini sejalan dengan teori yang ada, dengan pembelajaran melalui CD interaktif yang diterapkan pada anak usia dini tentunya dapat menstimulasi beberapa kecerdasan. Misalnya, kecerdasan kognitif yaitu dengan bertambahnya pengetahuan anak dan kemampuan anak dalam memahami sesuatu.Kecerdasan bahasa, yaitu yang dapat dilihat dari bertambahnya kosakata anak. Hal lain yang dapat dikembangkan dari pembelajaran melalui komputer bagi anak adalah stimulasi bagi perkembangan antara koordinasi mata dengan ketepatan gerak tangan. Secara tidak langsung pembelajaran melalui komputer juga menstimulasi bagi perkembangan motorik halus anak (Pangastuti, 2014: 68-69).

Langkah-langkah metode pemanfaatan komputer di TK Pelangi Kota Cirebon, yaitu sebagai berikut:

a) Guru memberitahukan anak untuk mematuhi aturan ketika menonton cerita pada TV.

b) Setelah itu guru menyetelnya dengan syarat anak-anak diam dan duduk di jarak tidak terlalu dekat dengan TV yang sudah ditentukan guru.

5) Metode bercerita 
Guru bercerita bukan hanya dengan boneka jari atau alat APE lainnya, namun dengan anak menonton DVD, guru bisa menanyakan kembali atau meminta anak untuk menceritakan kembali apa yang telah mereka lihat dan dengar. Sejalan dengan buku Pangastuti (2014: 68) bahwa metode bercerita merupakan pemberian pengalaman belajar bagi anak usia dini dengan membawakan cerita kepada anak secara lisan, cerita yang dibawakan guru harus menarik, mengundang perhatian anak dan tidak lepas dari tujuan pendidikan anak usia dini.dan biasa juga anak menceritakan kembali apa yng telah mereka dengar dan lihat.

Langkah-langkah metode bercerita di TK Pelangi Kota Cirebon, yaitu sebagai berikut:

a) Anak menonton DVD untuk mengetahui ceritanya atau guru itu sendiri yang bercerita.

b) Lalu guru merangsang anak untuk menceritakan kembali yang telah di dengarnya.

c) Anak diberi tugas untuk bermain peran dengan temannya.

d) Lalu guru menyimpulkan cerita yang telah dilihat anak.

6) Metode bermain peran

Metode bermain peran ini digunakan karena membuat anak senang, mereka saling berinteraksi dengan sesama temannya, secara tidak langsung anak mengenal dan menguasai bermacam kosa kata dari materi pembelajaran yang disampaikan oleh guru. Dalam bukunya Pangastuti (2014: 67) bahwa bercakap-cakap mengandung arti belajar mewujudkan kemampuan berbahasa reseptif dan ekspesif, anak akan mengembangkan bermacam kosa kata dalam berbagai tema yang akan mengacu pengembangan berbagai aspek perkembangan anak.

Langkah-langkah metode bermain peran di TK Pelangi Kota Cirebon, yaitu sebagai berikut:

a) Guru bercerita terlebih dahulu sesuai tema yang sudah ditentukan.

b) Setelah itu anak diberi tugas untuk memainkan peran yang telah diceritakan guru. Hal ini untuk melatih kosa-kata yang dimiliki setiap anak.

\section{c. Evaluasi Pembelajaran di TK Pelangi Kota Cirebon}

Alat penilaian yang biasa dilakukan oleh guru dengan berbagai catatan yang digunakan, diantaranya adalah catatan anekdot, penilaian mingguan, catatan observasi, catatan unjuk kerja, catatan penugasan, dan penilaian bulanan.

Penilaian perkembangan anak dengan kurikulum KTSP masih menggunakan bintang untuk menilai perkembangannya. Namun sekarang dengan adanya kurikulum 2013 penilaian diganti menjadi Belum Berkembang (BB), Mulai Berkembang (MB) dan Sudah Berkembang (SB). 


\section{SIMPULAN}

Perencanaan pembelajaran di TK Pelangi Kota Cirebon dengan rancangan dari kurikulum yang digunakan saat ini adalah kurikum 2013 PAUD sesuai dengan Undang-undang nomor 146 tahun 2014. Selain perencanaan juga ada rencana program pembelajaran semester yang setiap tahunnya di revisi bila ada masukan dari pihak tertentu.Berkaitan juga dengan rencana pelaksanaan pembelajaran mingguan dan rencana pelaksanaan pembelajaran harian yang disusun oleh guru masing-masing kelas.

Seperti dalam kurikulum 2013 menurut peraturan menteri pendidikan dan kebudayaan republik Indonesia nomor 146 tahun 2014. Dalam pasal 3 ayat (1) kurikulum PAUD disebut Kurikulum 2013 Pendidikan Anak Usia Dini. (2) Kurikulum 2013 Pendidikan Anak Usia Dini mengacu pada Standar Nasional Pendidikan Anak Usia Dini. Begitupun dalam pasal 5 ayat (1) Struktur Kurikulum PAUD menurut program-program pengembangan yang mencakup nilai agama dan moral, fisik motorik, kognitif, bahasa, sosial dan seni. Sejalan dengan PERMENDIKBUD no 137 tentang standar nasional pendidikan anak usia dini pasal 12 (2) perencanaan pembelajaran meliputi program semester (prosem), rencana pelaksanaan pembelajaran mingguan (RPPM) dan rencana pelaksanaan pembelajaran harian (RPPH).

Pelaksanaan pembelajaran di TK Pelangi Kota Cirebon ini berbasis edutainment di mana antara education (pendidikan) dan entertainment (hiburan) di padukan untuk mencapai pembelajaran yang lebih menyenangkan sesuai dengan tujuan awal pembelajaran.Pelaksanaan pembelajaran di TK Pelangi ini ada beberapa tahapan kegiatan, yaitu kegiatan awal, kegiatan inti dan kegiatan penutup.Kegiatan awal ini kaitannya dengan edutainment ini yang sering digunakan adalah metode bernyanyi dan bermain.Sedangkan di kegiatan inti kaitannya dengan edutainment yang sering digunakan adalah metode bercerita, pemanfaatan komputer, bermain peran, praktek langsung dan metode proyek.Setiap harinya berganti metode agar pembelajaran dikelas tidak monoton dan jenuh.

Sedangkan pada pasal 13 ayat (1) tentang pelaksanaan pembelajaran sebagaimana dalam pasal 11 huruf $\mathrm{b}$ dilakukan bermain secara interaktif, inspiratif, menyenangkan, kontekstual dan berpusat pada anak untuk berpartisipasi aktif serta memberikan keleluasaan bagi prakarsa, kreativitas dan kemandirian sesuai dengan bakat, minat dan perkembangan fisik serta psikologis anak. Dilanjut pada pasal 15 ayat (2) pelaksanaan pembelajaran mencakup (a) kegiatan pembuka, (2) kegiatan inti dan (3) kegiatan penutup. 
Evaluasi pembelajaran dilakukan oleh guru dengan menggunakan alat penilaian dengan catatan anekdot, penilaian mingguan, catatan observasi, catatan unjuk kerja, catatan penugasan, dan penilaian bulanan.Ini rutin dilakukan oleh guru, namun dibagi penilaiannya, satu guru memegang satu penilaian agar tidak bingung. Faktor penghambatnya adalah adanya tuntutan dari beberapa orangtua untuk membuat anaknya bisa menulis dan berhitung.Sedangkan faktor pendukung sendiri fasilitas yang lengkap dengan berbagai alat dan media belajar yang telah disediakan disetiap kelas.

\section{DAFTAR PUSTAKA}

Asrori.(2008). Memahami dan Membantu Perkembangan Peserta Didik. Untan Press.

Dariyo, Agoes. (2011). Psikologi Perkembangan. Bandung: PT Refika Aditama.

Darmansyah.(2011). Strategi Pembelajaran Menyenangkan dengan Humor.Jakarta: PT Bumi Aksara.

Desmita.(2012). Psikologi Perkembangan. Bandung: PT Remaja Rodakarya.

Eveline Siregar \& Hartini Nara.(2011). Teori Belajar dan Pembelajaran.Bogor : Penerbit Ghalia Indonesia.

Fadillah, Muhammad. (2014). Desain Pembelajaran PAUD. Jakarta: Ar-ruzz Media.

Fadillah dkk. (2014). Edutainment Pendidikan Anak Usia Dini. Jakarta: Kencana

Hadinoto, Siti Rahayu. (2014). Psikologi Perkembangan Pengantar dalam Berbagai Bagian. Yogyakarta: Gadjah Mada University Press.

Hamid, Sholeh. (2014). Metode Edutainment. Jogyakarta: Diva Press

Hamruni.(2009). Edutainment dalam Pendidikan Islam. Yogyakarta: Universitas Islam Negeri Sunan Kalijaga Yogyakarta.

Hariyanto dan Suyono.(2012). Belajar dan Pembelajaran. Bandung: Remaja Rosdakarya.

Hasnida. (2014). Analisis Kebutuhan Anak Usia Dini. PT Luxima Metro Media.

Idris, H Meity. (2014). Strategi Pembelajaran Yang Menyenangkan. Jakarta Timur: PT Luxima Metro Media.

King, A Laura. (2010). Psikologi Umum. Jakarta: Penerbit Salemba Humanika.

Majid, Abdul. (2013). Strategi Pembelajaran. Bandung: PT Remaja Rosdakarya.

Miles, Matthew B. \& A. Michael Huberman. (2009). Analisis Data Kualitatif. Jakarta: UI-Press.

Moeslichatoen.(2004). Metode Pengajaran di Taman Kanak-Kanak. Jakarta: PT Rineka Cipta.

Mulyasa.(2012). Manajemen PAUD.Bandung : PT Remaja Rosdakarya.

Mulyono.(2012). Strategi Pembelajaran. Malang: UIN-MALIKI PRESS.

Pangastuti, Ratna. (2014). Edutainment PAUD. Yogyakarta: Pustaka Pelajar.

Peraturan Menteri Pendidikan dan Kebudayaan RI No 137 Tahun 2014 tentang Standar Nasional Pendidikan Anak Usia Dini

Peraturan Menteri Pendidikan dan Kebudayaan RI No 146 Tahun 2014 tentang Kurikulum 2013 Anak Usia Dini

Putra, Nusa. (2013). Penelitian Kualila 100 ). Depok: Rajagrafindo Persada.

Sugiyono. (2010). Metode Penelitian Pendidikan Pendekatan Kuantitatif, Kualitatif, dan $R \&$ D. Bandung: Penerbit Alfabeta.

Sugiyono.(2012). Memahami Penelitian Kualitatif. Bandung: Penerbit Alfabeta. 
Sugiyono. (2014).Metode Penelitian Kuantitatif Kualitatif dan $R \&$ D.Bandung: Penerbit Alfabeta.

Sugiyono.(2015). Metode Penelitian Pendidikan. Bandung: Penerbit Alfabeta.

Suyadi.(2010). Psikologi Belajar Anak.Yogyakarta: PT Bintang Pustaka Abadi.

Suyadi.(2013). Strategi Pembelajaran Pendidikan Karakter.Bandung : PT Remaja Rosdakarya.

Syah, Mubibbin. (2011). Psikologi Pendidikan. Bandung: Remaja Rosdakarya.

Syaiful Bahri Djamarah \& Aswan Zain.(2013). Strategi Belajar Mengajar. Jakarta: PT Renika Cipta.

Susanto, Ahmad. (2011). Perkembangan anak usia dini. Jakarta: Prenada : Media Group.

Trianto. (2013). Desain Pengembangan Pembelajaran Tematik Bagi Anak Usia Dini. Jakarta : KENCANA.

Undang-Undang RI No 20 Tahun 2003 tentang Sistem Pendidikan Nasional

Uno B, Hamzah. (2014). Perencanaan Pembelajaran. Jakarta: PT Bumi Aksara.

Agustriana, Nesna. (2013). Pengaruh Metode Edutainment Dan Konsep Diri Terhadap Keterampilan Sosial Anak. Jakarta: PAUD PPs Universitas Negeri Jakarta. Jurnal UNJ. http://pps.unj.ac.id/journal/jpud/article/view/49. Diakses pada 18 Februari 2017.

Qurnialita, Aprilia Rizki. (2013). Penelitian Deskriptif Penerapan Konsep Edutainment dalam Pembelajaran Taman Kanak-kanak Kelompok B Usia 5-6 Tahun di TK Negeri 1 Sleman Yogyakarta. Skripsi UN Yogyakarta.http://eprints.uny.ac.id/15174/1/SKRIPSI\%20.pdf. Diakses pada 18 Februari 2017.

Shidik, A Syukur Purnama. (2014). Efektivitas Metode Edutainment Belanbe (Belajar dan Bermain) dalam Pembelajaran Menulis Teks Tanggapan Deskriptif.Skripsi UPI Bandung.http://repository.upi.edu/14074/6/S_IND_0801139_Chapter3.pdf. Diakses pada 18 Februari 2017. 